\title{
Education In Community Views In The Globalization Era
}

\author{
I Ketut Sudarsana ${ }^{1}$, Fatkul Anam ${ }^{2}$, I Gusti Ngurah Triyana ${ }^{3}$, I Made Dharmawan ${ }^{4}$, Rinandita \\ Wikansari $^{5}$, Achmad Daengs GS ${ }^{6}$, Asmara Indahingwati ${ }^{7}$, Erwinsyah Satria ${ }^{8}$, Yulfia Nora ${ }^{9}$ \\ \{'iketutsudarsana@uhnsugriwa.ac.id\} \\ ${ }^{1,3,4}$ Universitas Hindu Negeri I Gusti Bagus Sugriwa Denpasar, Bali, Indonesia, ${ }^{2}$ Universitas Wijaya \\ Kusuma, Surabaya, Indonesia, ${ }^{5}$ Politeknik APP Jakarta, Indonesia, ${ }^{6}$ Departement Management, \\ Universitas 45 Surabaya, Surabaya, Indonesia, ${ }^{7}$ Management Science, School of Economics Indonesia \\ "STIESIA" Surabaya, Indonesia, ${ }^{8,9}$ Elementary School Teacher Education Program, Faculty of Teacher \\ Training and Education, Universitas Bung Hatta, Padang, Indonesia
}

\begin{abstract}
Education as explained above, the point is humanizing human beings based on the Pancasila and the 1945 Constitution. This, of course, will have different meanings when viewed today, education is used as a way to find jobs. So that the graduates produced may not necessarily have a good attitude or character. Therefore, education that has a meaningful and purposeful goal (humanizing humans) must be returned by not making education as a land to draw human beings as workers only. The government as the executor of the task should not only look at the challenges of the work world but also need to pay attention to the moral degradation that occurs in Indonesian society today.
\end{abstract}

Keywords: Education; Community; Globalization Era

\section{Introduction}

As is well known, the foundation of education in Indonesia is Pancasila and the 1945 Constitution as stated in Law Number 20 of 2003 Chapter 1, Article 1, paragraph 2 which states: national education is education based on Pancasila and the Constitution of the Republic of Indonesia 1945, which was rooted in religious values, Indonesian national culture and responsive to the demands of changing times. And in the 1945 Constitution, the Government mandates and organizes a national education system that increases faith and devotion to God Almighty and noble character in the framework of educating the nation's life which is regulated by law. If observed from the two explanations of education, education in Indonesia emphasizes more on changes in attitudes that are in accordance with religious teachings so that later every Indonesian citizen is expected to have faith and piety to God Almighty. In addition, in the 1945 Constitution states that intelligence in education in Indonesia is not just a great value or won in class, but more on aspects of attitude that is faithful, pious, and noble.

It is also stated in Chapter II article 3 that reads, "national education functions to develop the ability and shape of dignified national character and civilization in order to educate the life of the nation, aims to develop the potential of students to become believers and fear of God Almighty, noble, healthy, knowledgeable, capable, creative, independent, and a democratic and responsible citizen. " Thus, education in Indonesia is a process that is held in order to 
improve the quality of its citizens, so that they become citizens who are faithful, pious and noble.

But when compared with the facts in the field, maybe the mandate stated in Pancasila, the 1945 Constitution, and Law No. 20 of 2003 is still far from expectations. Because there are still many human resources in Indonesia who lack faith, fear, and nobility. The reason is that there are still many people who commit various violations of the law, such as corruption, stealing, clashes, and so forth. This is certainly tarnishing the world of education in Indonesia. In addition, people's views on education are no longer a process of cultivating good attitudes, but education is viewed as a process that will later provide jobs. So that the current phenomenon, education is defined as a way to get a job. This can be seen, when parents are confused about finding a school for their children [1] [2]. Supposedly, the child is the one who determines where the school is comfortable, but parents who have the power to think about sending their children to school who after graduation can provide jobs.

This kind of phenomenon if ignored, it will further worsen the world of education in Indonesia and certainly not in accordance with the mandate of Pancasila and the 1945 constitution [3]. Therefore, there needs to be concrete action to revive the public about the meaning of education itself. So that in the future, education is no longer seen as a way to seek jobs only.

\section{Method}

This research uses library research methods. Because the library research data is obtained only through books, so in conducting research, researchers must read and record the main material in research. The data analysis technique used in this study is a qualitative data analysis technique because the data obtained are qualitative data so it is not in the form of numbers, but data in the form of phenomena and cases in the form of reports and thoughts of education experts, so that they require careful thinking in solving research problems.

\section{Result and Discussion}

\subsection{The Nature of Education for Humans}

According to the National Education System Law No. 20 of 2003, Article 1 paragraph (1) states that education is a conscious and planned effort to realize the learning atmosphere and learning process so that students actively develop their potential to have spiritual power, selfcontrol, personality, intelligence, noble character, and skills that are needed by themselves, society, nation and state. From the definition of education above, it can be remembered that education is very important for humans. Therefore, no country does not provide education for its people.

Creating human beings who are faithful, pious and noble, the role of education as a means, of course must be humanistic. Because education provides space for teaching moral ethics, and all the noble rules that guide students to reach humanization [4]. In various programs about education also mentioned, if education functions to humanize humans [5]. This is because humans live in the world in a state that has not been determined to become what or become who later because of that the aspects of human nature are basically a potential that is 
at the same time a task that must be realized by everyone [5]. Therefore, there needs to be education to direct or guide so that it can raise human potential in a good direction. In addition, education intends to make humans more perfect, making humans improve their lives from natural to cultured.

\subsection{Education and Jobs}

The rapid globalization by bringing the ideology of capitalism makes people more concerned with the results obtained. So if there is money, moves, if there is no money, it doesn't work. Today, money has an important role in the rotation of human life. If there is no money, then humans will feel miserable. This is evidenced by the many thefts that are increasingly alarming. In addition to stealing, the culture of corruption committed by members of the House of Representatives and the government is still there. Even though the government and the House of Representatives have launched a fight against corruption. In the community itself, in addition to stealing also has developed a debt lifestyle, which is caused by humans themselves who have adopted a consumer culture, thus placing itself as a consumer that is increasingly widespread [6]. Furthermore, Atmadja stated that this kind of situation is nothing else because of the influence of market religion which has undermined human life so that chronic lack of money is unavoidable in human life [6].

Indeed, money currently has an important role. But keep in mind, that in economics, money is a tool for payment, so it is not the money needed, but the desire behind money is what humans need money. Humans' great desire for luxury goods, makes them uncontrolled to get money quickly but does not need to bother. In addition, the demands for basic necessities that are increasingly expensive also make money the main human need. The demand for globalization as it is now has a big impact on the entire life of the community, one of which is education. Parents as child facilitators in the world of education, require the existence of outcomes or income due to the magnitude of opportunity costs. Therefore do not be surprised if today many parents send their children to school who can provide jobs quickly after graduation. Because of this factor, many private schools are now flooded with students. In fact, it is clearly stated that schools are not a factory or company to seek profit [7].

In the law, it is stated that education is held to provide skills for students. However, this is not merely a reference if education is used as an arena to find work. Indonesia is also not a United States country which views education as merely a way to make children learn [8]. Here education loses values, namely the subjective aspects of human beings who should be respected for losing their meaning and reduced to the quantity of material achievements only [7]. In contrast to Indonesia, where Pancasila as the foundation of education in Indonesia has a definite vision, namely the complete Indonesian people imbued by the principles of Pancasila [8]. From the explanation of the Pidarta, it is clear that education in Indonesia is adjusted to the contents of the Pancasila itself, namely:

a. Belief in the One and Only God, in this case the Pancasila teaches that every Indonesian man believes in God Almighty in accordance with their respective religions. Pancasila does not teach to interfere in the affairs of each religion, because human relations with God are already at the level of their respective religions.

b. Humanism, in essence, is to discuss human beings themselves. Humans in their existence are aware that their existence is in equal togetherness and dependence on fellow human beings.

c. A unified Indonesia teaches that even though it's different but remember that the people of Indonesia have one homeland, one nation, and one language. 
d. Democracy, led by the wisdom of the representatives of the People, shows togetherness in solving problems faced by the people themselves. The solution to this problem is carried out in a deliberation and / or representation. It is hoped that the problem can be resolved through deliberation to agree.

e. Social justice for all Indonesians, actually involves a relationship with yourself, with other people, or the community, and with the environment, and God. Fair in the context is balance, where there is no overlap or favoritism. All are considered equal and have rights [9].

These are the five points of educational goals based on Pancasila. So that education in Indonesia has a very noble goal, as explained earlier. Especially at this time Indonesia has launched character education that clearly emphasizes the character possessed by students. Character education as explained by Astawa is an effort that is systematically designed and implemented to help students understand the values of human behavior that relate to God Almighty, self, fellow human beings, the environment, and nationality manifested in thoughts, attitudes, feelings, words, and actions based on the norms of religion, law, etiquette, culture and customs [10].

\subsection{Vocational High School Hegemony}

Another factor that causes a change in the mindset of the community towards education, because of the hegemony of private schools that are growing rapidly at this time. In its promotion, the vocational school gives guarantees to all students who study at the vocational school, after graduation, they will immediately get a job. This causes people to flock to their children in vocational high schools rather than in the country. This usually happens to people with lower middle class economies. The government in this case as an education provider also supports the existence of vocational schools, this can be seen from the Vice President Jusuf Kalla's statement to the Ministry of Education and Culture to increase the development of vocational high schools (SMK), rather than public schools to reduce unemployment.

Furthermore, the vice president also stated "If you are looking for work that requires expertise, it is in a vocational school (concerning human resources). So why should vocational school has more number than public schools, if not, then the (general) school can be a factory of unemployment. As stated by the vice president, this will certainly have an impact on increasing vocational hegemony on education. So that the purpose of education which is initially to educate character or attitude, to be deviated, namely education is seen as an activity to educate personnel for a business. And the people's view of education is a place to find a way or job opportunity.

\section{Conclusion}

Character education must be fully supported, not to be limited to discourse which is not carried out. The construction of schools should not be overtaken, whether public schools or vocational schools must get the same attention. Indeed, in this case, the challenges of the working world in the global era are very tight. If the government really wants to prepare quality human resources, namely having good work skills and character, then it can be done by, namely (1) Primary school (SD), the allocation of time for subjects related to attitude development must be allocated more time. Because it is at this level that children begin to recognize which is good and bad. (2) Middle and high school / vocational high school levels 
can be given subjects that are related to work skills, but still provide time allocation for subjects related to attitude education. These are some ways that can be done, which are solely to awaken all parties to the true meaning of Indonesian education.

\section{References}

[1] F. Fincham and J. Jaspars, "Attribution of responsibility to the self and other in children and adults," J. Pers. Soc. Psychol., 1979.

[2] S. K. D. A et al., "Belajar Melalui Bermain untuk Pengembangan Kreativitas dan Kognitif Anak Usia Dini," Surya, 2016.

[3] S. Soeprapto, "Implementasi Pancasila Dalam Kehidupan Ber Masyarakat Berbangsa Dan Bernegara," J. Ketahanan Nas., 2016.

[4] A. Wibowo, Pendidikan Karakter Berbasis Sastra. Yogyakarta: Pustaka Pelajar, 2013.

[5] D. Wahyudin, dkk., Pengantar Pendidikan. Jakarta: Universitas Terbuka, 2008.

[6] N. B. Atmadja, Ajeg Bali Gerakan, Identitas Kultural, dan Globalisasi. Yogyakarta: LKiS., 2010 .

[7] F. Mu'in, Pendidikan Karakter Konstruksi Teoretik \& Praktik. Yogyakarta: Ar-Ruzz Media., 2011.

[8] M. Pidarta, Landasan Kependidikan Stimulus Ilmu Pendidikan Bercorak Indonesia. Jakarta: Rineka Cipta, 2013.

[9] U. Sadulloh, Pengantar Filsafat Pendidikan. Bandung: Alfabeta, 2012.

[10] P. Suweka, Sugiharta, Oka and I. K. Sudarsana, "Hypnotic Learning Characteristics On Sisya Brahmakunta Community In Denpasar," Vidyottama Sanatana Int. J. Hindu Sci. Relig. Stud., vol. 1, no. 2, pp. 132-145, 2017. 